\title{
First nesting records for Black Sparrow- hawk Accipiter melanoleucus in the Northern Cape, South Africa
}

Julius H. Koen and Brian W. Culver

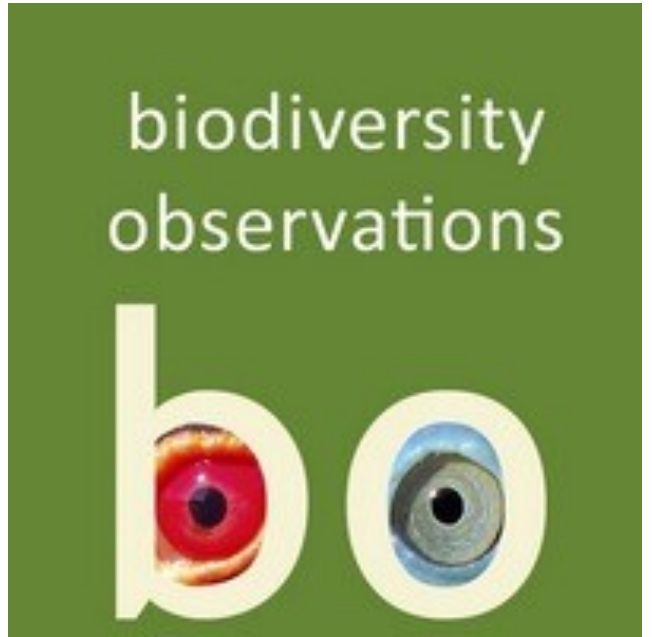

Koen JH and Culver BW 2022. First nesting records for Black Sparrowhawk Accipiter melanoleucus in the Northern Cape, South Africa. Biodiversity Observations 12: 1-5

black sparrowhawk, nesting, distribution

23 February 2022

DOI: https://doi.org/10.15641/bo.1187 


\section{Ornithology}

\section{First nesting records for the Black Sparrowhawk Accipiter melanoleucus in the Northern Cape, South Africa}

Julius H. Koen, Cape Falconry Club, 38 Nederburg Avenue, Kimberley 8301, South Africa

email: julius.koen@gmail.com

Brian W. Culver, Citizen Scientist, 67 Aviva Road, Kimberley, 8301, South Africa

\begin{abstract}
Black sparrowhawks Accipiter melanoleucus have expanded their range westwards into areas previously unsuitable due to a lack of appropriate tree cover. They now occur in areas where exotic trees (mainly Eucalyptus and Pinus species) have become established: forestry plantations, urban areas and infestations along rivers. This paper reports the status of black sparrowhawks in the Northern Cape, and the discovery of two nests in Pinus plantations close to Nieuwoudtville in 2019. It is likely that this area was colonised from the Western Cape.
\end{abstract}

\section{Introduction}

Black sparrowhawks Accipiter melanoleucus are recent arrivals in certain parts of South Africa (Curtis and Koeslag 2004; Tate 2016). As a mostly forest and well-developed woodland species (Curtis et al. 2005; Curtis et al. 2007) they were restricted to areas with suitable trees of a specific density and height for breeding (Malan and Robinson 2001), largely in the eastern half of South Africa. Some of the areas where they now occur, and breed, were previously unsuitable due to a lack of appropriate tree cover. These areas have been altered due to human-induced changes such as the planting of exotic trees (Eucalyptus and Pinus spp.) for forestry purposes, the proliferation of these species outside of designated forestry areas, and the development of urban gardens (Curtis and Koeslag 2004; Wreford 2014). It was only from the 1950's that they established in some numbers on the Cape Peninsula with the first breeding records from about 1993 to the late 1990's (Oettlé 1994; Curtis and Koeslag 2004; Curtis et al. 2007). The Cape Peninsula previously consisted of various, mostly treeless, Fynbos vegetation types with scattered Afromontane Forest patches, making it largely unsuitable for black sparrowhawks.

They are now well-established in the region with numerous breeding pairs (at least 40 ) both outside and within urban gardens (Curtis and Koeslag 2004). They have also increased their distribution range from the east into the Free State, with at least 11 breeding pairs in the city of Bloemfontein and a total of 20 within a $100 \mathrm{~km}$ radius (T. McPherson pers. comm. 2019). Black sparrowhawks have been recorded in all pentads around Bloemfontein especially in the pentads south and east of Bloemfontein. They have also expanded west of Bloemfontein with a healthy breeding population along the Modder and Riet Rivers around the town of Jacobsdal, close to the Northern Cape border (Julius Koen pers. obs.); breeding pairs have been well established over the past 30-40 years (S. Squires pers. comm. 2019). All known nests in that area are in Eucalyptus sp. trees of which some have, unfortunately, been destroyed by the Working for Water Programme. From the Northern Cape border westwards, the habitat becomes unsuitable for Black Sparrowhawk. Nests may possibly be found just within the Northern Cape border around the town of Modder River.

In the Northern Cape, black sparrowhawks have largely been recorded as vagrants as indicated by the SABAP2 data (http:// sabap2.adu.org.za). They have been seen at Kamieskroon in Namaqualand and more commonly around the towns of Nieuwoudtville and Calvinia in the southwest of the province. In addition, they have also been observed just east of the town of Garies in Namaqualand as well as about half-way between the towns of Victoria West and Vosburg in the Karoo (E. Herrmann 2019 pers. comm.). In January 2019, JK received an injured juvenile male black sparrowhawk for rehabilitation purposes that was found on the golf course in the town of Lime 

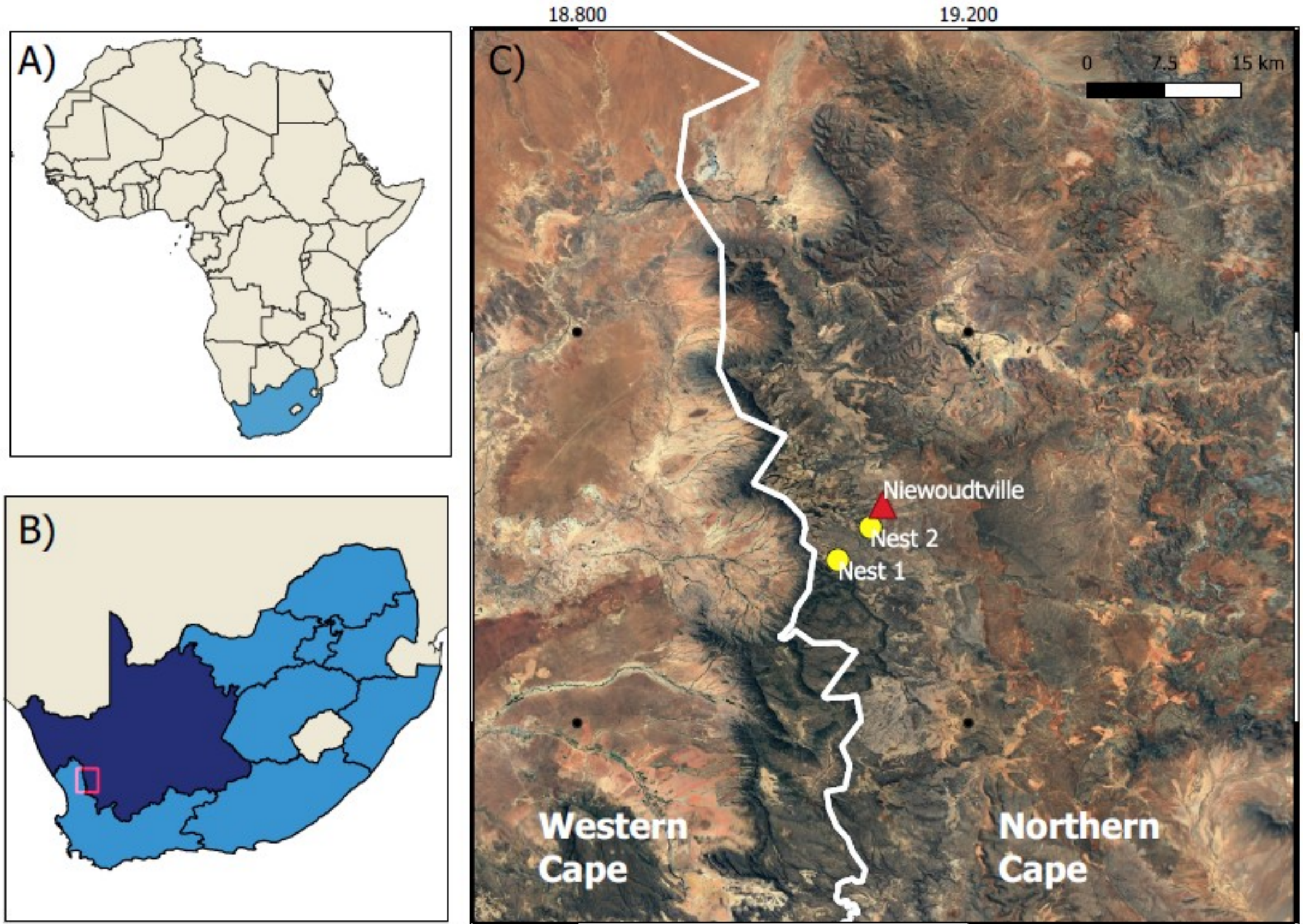

\section{B)}

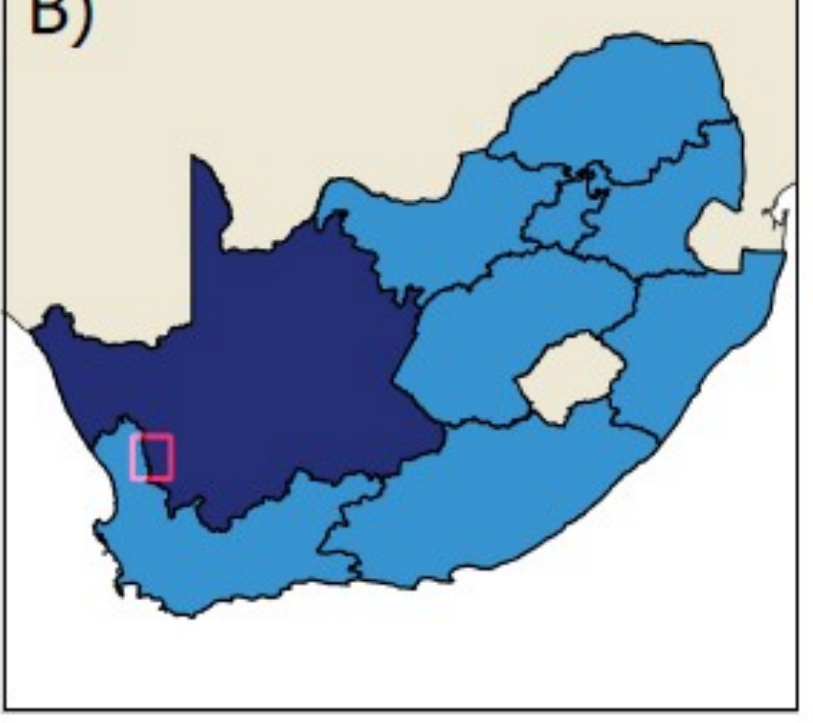

Figure 1: Maps indicating the location of the Black Sparrowhawk nests in relation to the Western Cape and Northern Cape Provincial border and the town of Niewoudtville. 
Acres $\left(28^{\circ} 22^{\prime} \mathrm{S}, 23^{\circ} 27^{\prime} \mathrm{E}\right)$. This record is the furthest north for the species in the province. No nesting or breeding records for the black sparrowhawk are known in the Northern Cape (Hockey et al. 2005; A. Jenkins 2019 pers. comm.; G. Tate 2019 pers. comm.).

Due to the more regular observations of black sparrowhawks in the southwest of the Northern Cape, it was decided to focus on this area to find nesting sites which would be the first for the Northern Cape. JK visited the Nieuwoudtville area in March 2019 during which he raised awareness about black sparrowhawks and tried to identify suitable nesting areas to be visited in the breeding season. Nieuwoudtville is on the Bokkeveld Escarpment (Fig 1.) and the vegetation is a mosaic of various Fynbos and Renosterveld veld types with isolated patches of Afromontane Forest vegetation. Large parts of the area have been converted to rooibos tea croplands and grazing for livestock. Alien trees (Pinus, Eucalyptus and Populus spp.) have also been introduced to the area. These species have spread and formed patches of different sizes which could be suitable as nesting sites for black sparrowhawks.

During early September 2019, JK was informed by Mandy Schumann (Department of Environment and Nature Conservation) that two field rangers (Johannes Afrika and Nathan Kotze) may have found a black sparrowhawk nest on the Oorlogskloof Nature Reserve about $10 \mathrm{~km}$ southwest of Nieuwoudtville. The area was visited on 26 September 2019 and the nesting species was positively identified as black sparrowhawk. This nest is right at the entrance area to the reserve $\left(31^{\circ}\right.$ 26 'S, $\left.19^{\circ} 04^{\prime} \mathrm{E}\right)$. The nest is in a Pinus sp. at a height of about $13.4 \mathrm{~m}$ (Fig.2). Although the female (a light phase) (Fig. 3) was very territorial and vocal around the nest, the male was not seen and only heard.

Unfortunately, there was a forest fire in the largest Pinus plantation in the area during the site visit. This plantation was deemed to be the most suitable breeding habitat for black sparrowhawks but plans to search this area for further nests had to be cancelled. Another potential site was identified and visited where nest number two was found. This nest was on the farm Hotbergfontein about $5 \mathrm{~km}$ south of Niewoudtville $\left(31^{\circ} 23^{\prime} \mathrm{S}, 19^{\circ} 05^{\prime} \mathrm{E}\right)$. The nest was also in a Pinus sp. at a height of about $12.9 \mathrm{~m}$ (Fig. 4). The female at the nest (a dark phase) (Fig .5) was very vocal and territorial around the nest. The male was

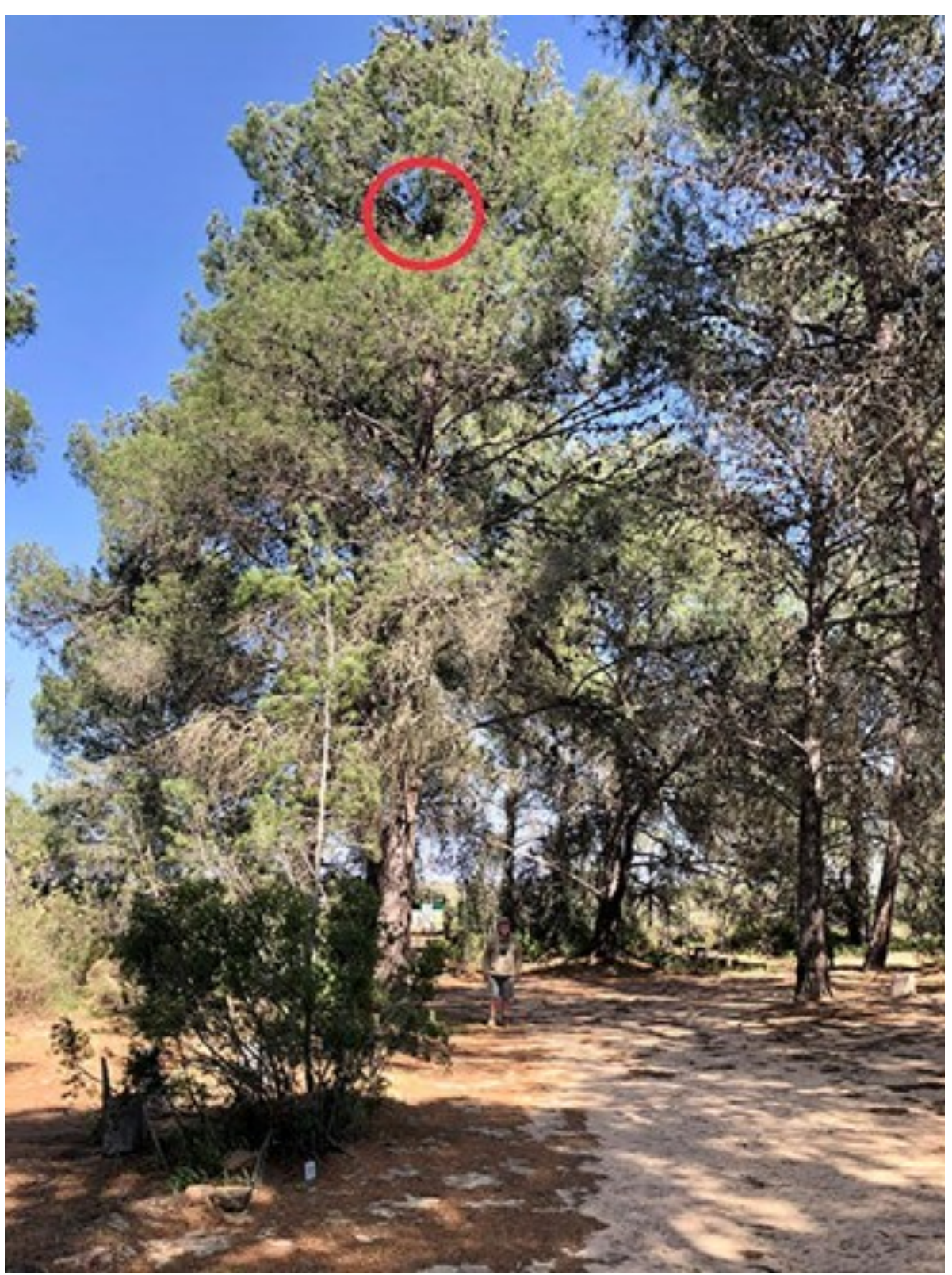

Figure 2: Nest 1 at the entrance to the Oorlogskloof Nature Reserve, Nieuwoudtville. 


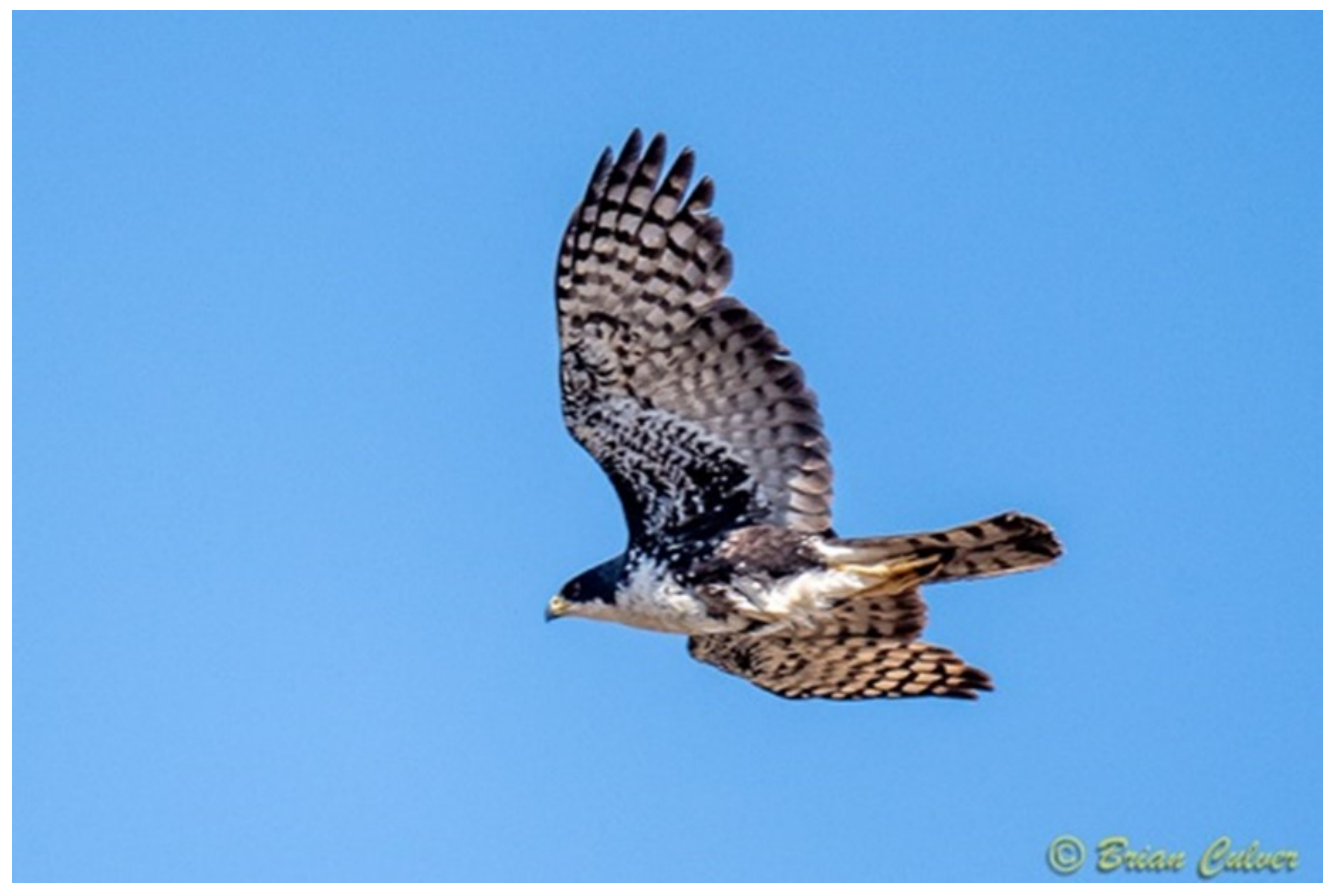

Figure 3: Light phase female from nest 1.

not seen but only heard. It was suspected that both pairs were in the latter stages of incubation or with small young.

Although only one day was spent trying to find nests, it is suspected that there may be a healthy black sparrowhawk population in the area as JK (pers obs.) has previously seen both adults and juveniles in the area and a juvenile and adult bird were found dead in the town of Nieuwoudtville, presumably killed with an air rifle (M. Schumann pers. comm. 2019). The closest breeding record for black sparrowhawks to Nieuwoudtville is at the Driehoek Guest Farm, $40 \mathrm{~km}$ southeast of Clanwilliam, Western Cape (Z. Vermaak 2019 pers. comm.) and about $145 \mathrm{~km}$ south of Niewoudtville. It is therefore suggested that the Nieuwoudtville black sparrowhawk population may have been colonised from the Western Cape. It is possible that black sparrowhawks may be breeding in other suitable stands of exotic trees towards the interior of the Northern Cape. However, no nests have been found.

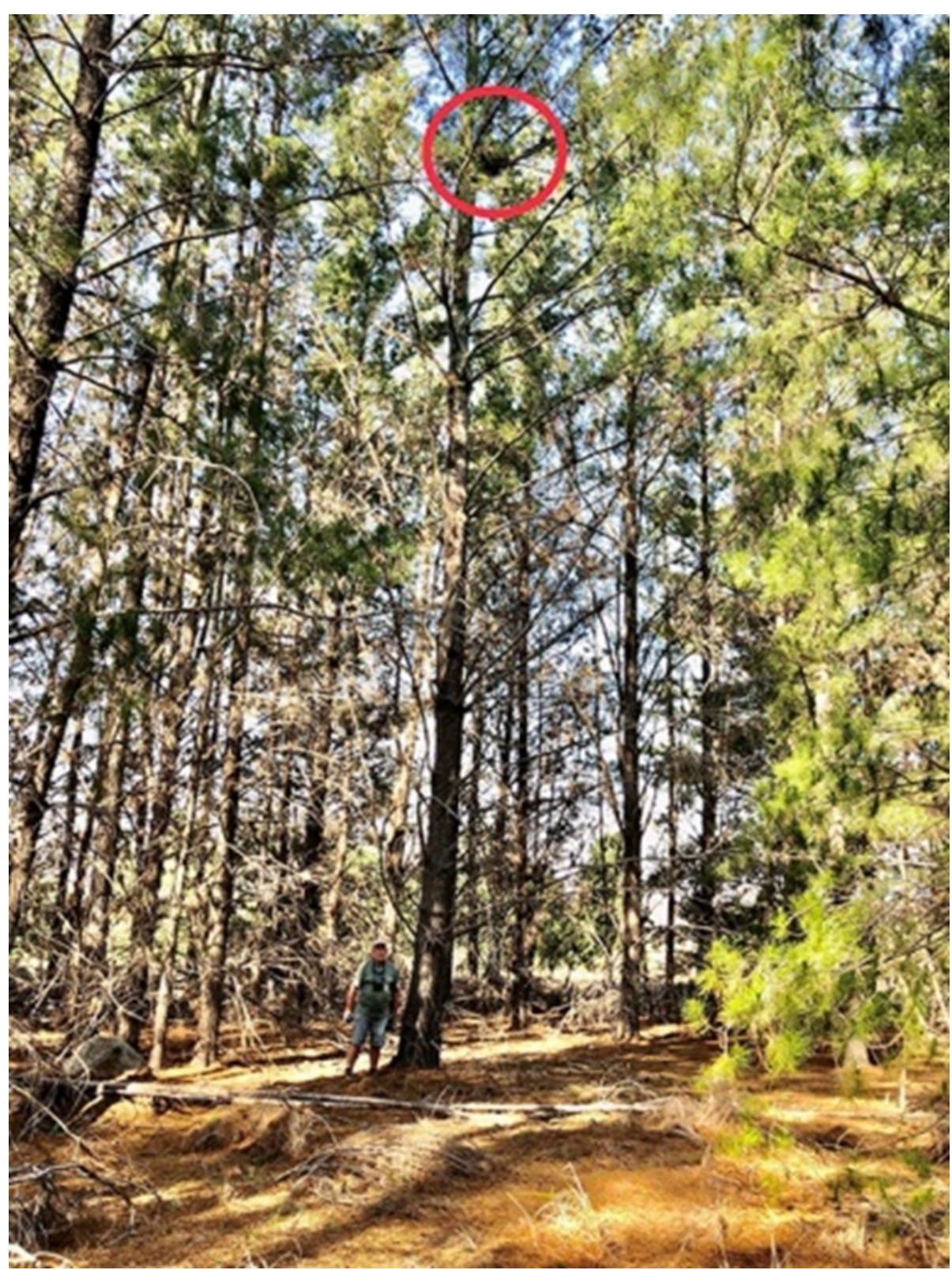

Figure 4: Nest 2 on the farm Hotbergfontein, Nieuwoudtville. 


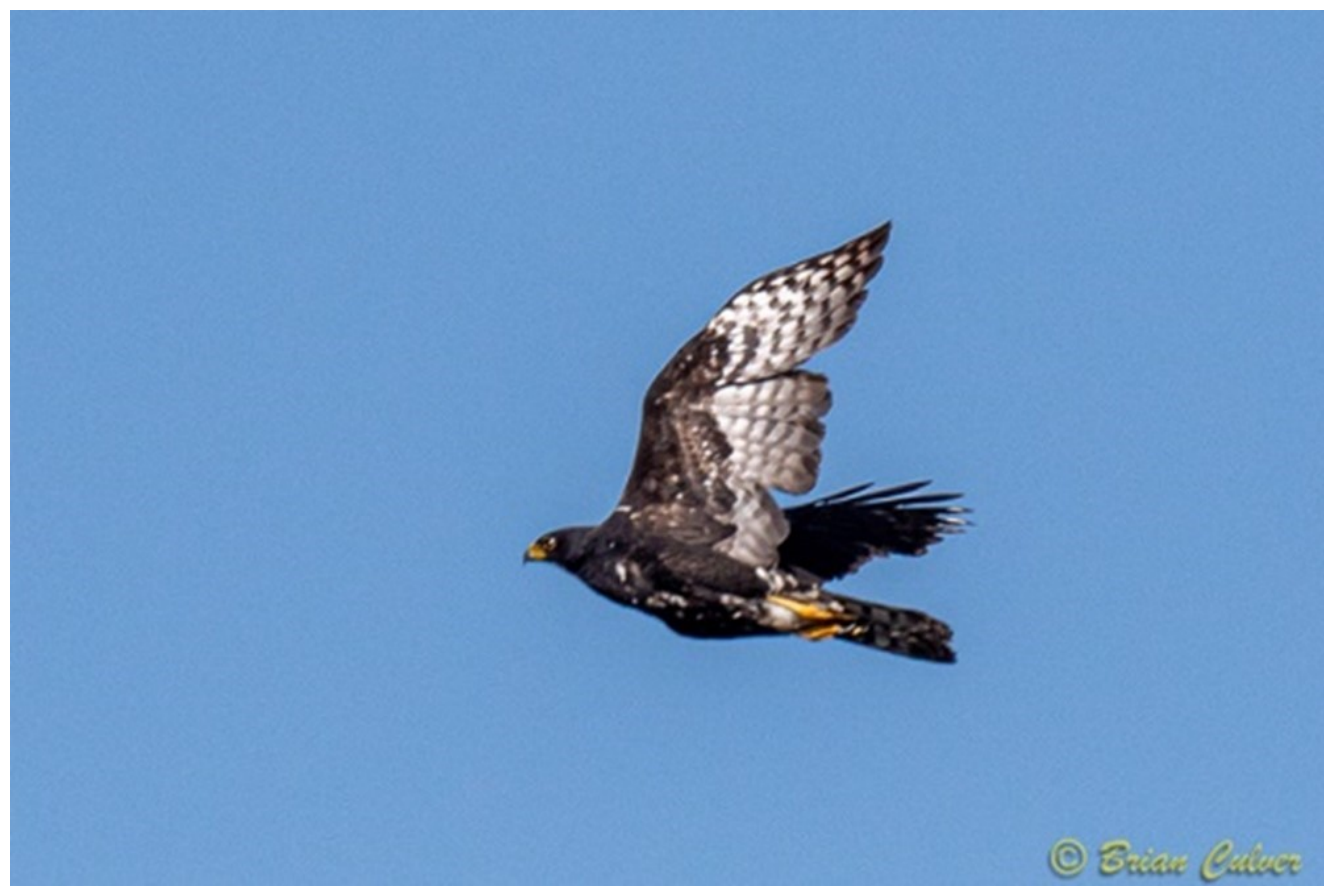

Figure 5: Dark phase female from nest number two.

\section{Acknowledgements}

We would like to thank Mandy Schumann of the Department of Environment and Nature Conservation for generating local interest in Black Sparrowhawks in the greater Nieuwoudtville area, for arranging access to the Oorlogskloof Nature Reserve and for hosting us. Reserve Manager Petrus Nkosi is thanked for providing access to the Oorlogskloof Nature Reserve. We are deeply indebted to Johannes Afrika and Nathan Kotze for locating the first nest. Marguerite McGregor is also thanked for access to her farm Hotbergfontein. Doug Harebottle is thanked for his comments on an earlier draft. Thank you to Itxaso Quintana for preparing the map in Fig 1.

\section{References}

Curtis O, Koeslag A 2004.Forest enigma. Africa - Birds \& Birding 9 (2): 46-52.

Curtis O, Malan G, Jenkins A, Myburgh N 2005. Multiple-brooding in birds of prey: South African Black Sparrowhawks Accipiter melanoleucus extends the boundaries. Ibis 147:11-16.

Curtis O, Hockey PAR, Koeslag A 2007. Competition with Egyptian Geese Alopochen aegyptiaca overrides environmental factors in determining productivity of Black Sparrowhawks Accipiter melanoleucus. Ibis 149: 502-508.

Hockey PAR, Dean WRJ, Ryan PG (eds) 2005. Roberts Birds of Southern Africa. 7th edn. John Voelcker Bird Book Fund, Cape Town.

Malan G, Robinson ER 1999. Nest site selection by Black Sparrowhawks Accipiter melanoleucus: Implications for managing exotic pulpwood and sawlog forests in South Africa. Environmental Management 28: 195-205.

Oettlé EE 1994. Black Sparrowhawk breeds in the Cape Peninsula. Promerops 21:2-7.

Tate GJ 2016. Exploring the maintenance of plumage polymorphism in the Black Sparrowhawk. PhD. Thesis, University of Cape Town.

Wreford EP. 2014. The ecology of Black Sparrowhawks Accipiter melanoleucus in KwaZulu-Natal. MSc Thesis, University of KwaZuluNatal.

Paper edited by Megan Loftie-Eaton and Les Underhill The Biodiversity and Development Institute 


\section{Biodiversity Observations}

The scope of Biodiversity Observations includes papers describing observations about biodiversity in general, including animals, plants, algae and fungi. This includes observations of behaviour, breeding and flowering patterns, distributions and range extensions, foraging, food, movement, measurements, habitat and colouration/plumage variations. Biotic interactions such as pollination, fruit dispersal, herbivory and predation fall within the scope, as well as the use of indigenous and exotic species by humans. Observations of naturalised plants and animals will also be considered. Biodiversity Observations will also publish a variety of other interesting or relevant biodiversity material: reports of projects and conferences, annotated checklists for a site or region, specialist bibliographies, book reviews and any other appropriate material. Further details and guidelines to authors are on the journal website (https://journals.uct.ac.za/index.php/BO/).

ISSN 2219-0341

Editor: LG Underhill

biodiversity

observations

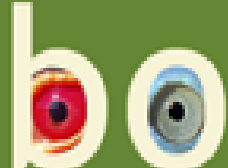

Biodiversity Observations is powered by Open Journal Systems (OJS) and is hosted by the University of Cape Town Libraries. OJS is an open source software application for managing and publishing scholarly journals. Developed and released by the Public Knowledge Project in 2001 , it is the most widely used open source journal publishing platform in existence, with over 10,000 journals using it worldwide. 